\title{
Fatty acid profile of milk from cows fed palm kernel cake
}

\section{Perfil de ácidos graxos do leite de vacas alimentadas com torta de dendê}

\author{
Leidiane Reis Pimentel ${ }^{1 *}$; Fabiano Ferreira da Silva²; Robério Rodrigues Silva²; \\ Eli Santana de Oliveira Rodrigues ${ }^{1}$; Murilo de Almeida Meneses ${ }^{1}$; \\ Antônio Ferraz Porto Júnior'; Dicastro Dias de Souza ${ }^{1}$; Gonçalo Mesquita da Silva ${ }^{1}$; \\ Camile Carvalho Pacheco ${ }^{3}$; Paulo Andrade de Oliveira ${ }^{4}$
}

\begin{abstract}
To evaluate the fatty acid profile of milk from cows fed palm kernel cake (PKC), 12 Holstein $\times$ Zebu crossbred cows were kept in the feedlot, distributed into a triple $4 \times 4$ Latin square, and fed the following treatments: 1) control; 2) inclusion of $50 \mathrm{~g} \mathrm{PKC} / \mathrm{kg}$ in the total dry matter (TDM); 3) inclusion of 100 $\mathrm{g} \mathrm{PKC} / \mathrm{kg}$ in the TDM; and 4) inclusion of $150 \mathrm{~g} \mathrm{PKC} / \mathrm{kg}$ in the TDM. Milk samples from the morning and afternoon milkings were collected in the amount of $1 \%$ of the daily production of each animal; subsequently, $100-\mathrm{mL}$ subsamples were frozen for analysis of the fatty acid profile. Inclusion of PKC did not change the concentration of short-chain fatty acids or myristoleic $\left(\mathrm{C}_{14: 1}\right)$, pentadecenoic $\left(\mathrm{C}_{15: 1}\right)$, palmitic $\left(\mathrm{C}_{16: 0}\right)$, and palmitoleic $\left(\mathrm{C}_{16: 1}\right)$ fatty acids. Concentrations of medium-chain and lauric $\left(\mathrm{C}_{12: 0}\right)$ and myristic $\left(\mathrm{C}_{14: 0}\right)$ fatty acids increased linearly $(\mathrm{P}<0.05)$. A decreasing linear effect was observed $(\mathrm{P}<0.05)$ on the concentration of the $\mathrm{C}_{15: 0}$ fatty acid. No effects were observed ( $\left.\mathrm{P}>0.05\right)$ on the long-chain fatty acids and those of the omega 6 and 3 series; on the ratio between poly-unsaturated and saturated fatty acids; or on the ratio between the fatty acids of the omega 6/omega 3 series. The concentration of conjugated linoleic acid was not influenced $(\mathrm{P}>0.05)$ by inclusion of $\mathrm{PKC}$ in the diet. Addition of palm kernel cake to the diet of lactating cows influences the concentration of medium-chain fatty acids, and of lauric $\left(\mathrm{C}_{12: 0}\right)$, myristic $\left(\mathrm{C}_{14: 0}\right)$, and pentadecanoic $\left(\mathrm{C}_{15: 0}\right)$ fatty acids in their milk.
\end{abstract}

Key words: Conjugated linoleic acid. Monounsaturated. Milk production. Polyunsaturated.

\section{Resumo}

Para avaliar o perfil de ácidos graxos do leite de vacas alimentadas com torta de dendê (TD) foram utilizadas 12 vacas mestiças Holandês x Zebu, mantidas em confinamento, distribuídas em um triplo Quadrado Latino 4 x 4 e recebendo os seguintes tratamentos: 1) controle; 2) inclusão de $50 \mathrm{~g} \mathrm{TD} / \mathrm{kg}$ na matéria seca total (MST); 3) inclusão de $100 \mathrm{~g} \mathrm{TD} / \mathrm{kg}$ na MST e 4) inclusão de $150 \mathrm{~g} \mathrm{TD} / \mathrm{kg}$ na MST. Amostras de leite da ordenha da manhã e da tarde foram coletadas na quantidade de $1 \%$ da produção diária de cada animal, após subamostras de $100 \mathrm{~mL}$ foram congeladas para posterior análise do perfil

\footnotetext{
${ }^{1}$ Discentes do Curso de Doutorado do Programa de Pós-Graduação em Zootecnia, Universidade Estadual do Sudoeste da Bahia, UESB, Itapetinga, BA, Brasil. E-mail: leidyrp@yahoo.com.br; eli.uesb@hotmail.com; dddmeneses@msn.com; ferrazporto@, hotmail.com; dicastro@zootecnista.com.br; gon_zootecnia23@hotmail.com

2 Profs., Departamento de Tecnologia Rural e Animal, UESB, Itapetinga, BA, Brasil. E-mail: ffsilvauesb@hotmail.com; rrsilva. uesb@hotmail.com

${ }^{3}$ Discente do Curso de Mestrado do Programa de Pós-Graduação em Zootecnia, UESB, Itapetinga, BA, Brasil. E-mail: kmilipc@ hotmail.com

${ }^{4}$ Pós-Doutorando do Programa de Pós-Graduação em Zootecnia, Universidade Federal da Bahia, UFBA, Salvador, BA, Brasil. E-mail: pazootecnista@hotmail.com

* Author for correspondence
} 
em ácidos graxos. A inclusão de TD não alterou as concentrações dos ácidos graxos de cadeia curta e dos ácidos graxos Miristoleico $\mathrm{C}_{14: 1}$, Pentadecenoico $\mathrm{C}_{15: 1}$, Palmítico $\mathrm{C}_{16: 0}$ e Palmitoleico $\mathrm{C}_{16: 1}$. Houve efeito linear crescente $(\mathrm{P}<0,05)$ para as concentrações dos ácidos graxos de cadeia média, Láurico $\mathrm{C}_{12: 0} \mathrm{e}$ Mirístico $\mathrm{C}_{14: 0^{0}}$. Para a concentração do ácido graxo $\mathrm{C}_{15: 0}$, houve efeito linear decrescente $(\mathrm{P}<0,05)$. Não foram observados efeitos $(\mathrm{P}>0,05)$ para os ácidos graxos de cadeia longa e da série Ômega 6 e 3 , assim como, para a proporção entre os ácidos graxos poli-insaturados/saturados, e entre os ácidos graxos da série ômega 6/ômega 3 . A concentração do ácido linoleico conjugado não foi influênciada $(P>0,05)$ pela inclusão de TD na dieta. A inclusão de torta de dendê na dieta de vacas lactantes influencia a concentração dos ácidos graxos cadeia média, do ácido Láurico $\mathrm{C}_{12: 0}$, Mirístico $\mathrm{C}_{14: 0}$ e Pentadecanoico $\mathrm{C}_{15: 0}$.

Palavras-chave: Ácido linoleico conjugado. Monoinsaturados. Produção de leite. Poli-insaturados.

\section{Introduction}

Biodiesel is produced from vegetable oil or animal fat (MA; HANNA, 1999) via esterification or transesterification - the second being the most largely used method. Transesterification is a chemical reaction that occurs between vegetable oils or animal fats and ethanol and methanol, utilizing a catalyst, that also generates glycerol, a product with diverse applications in the chemical industry (CÂNDIDO, 2009). In addition to glycerol, the biodiesel production chain produces a number of other by-products (cake, meal, etc.) that can make up other sources of income to producers. Among the by-products used in animal feeding, the palm kernel cake has great potential not only because of its nutrient composition, but also because of its availability throughout the year and low cost, especially in high-producing regions, as is the case of North and Northeast Brazil (COSTA et al., 2009). The production of palm kernel cake involves grinding the palm (Elaeis guineensis), followed by pressing, which may or may not have an intermediate stage of peeling and cooking. During the pressing stage, the crude palm kernel oil is diverted to clarification, and the residual palm kernel cake is chilled and stored (SUE, 2001).

The fatty acid profile of the milk fat can be influenced by an array of factors, e.g.: the intensity of rumen biohydrogenation, non-lipid components of the diet, the influence of the lipid source on the microbial synthesis of fatty acids and de novo synthesis in the mammary gland, lactation stage and intestinal activity, and, in the mammary gland, the $\Delta 9$-desaturase enzyme (KENNELLY, 1996). The milk fat is synthesized from the fatty acids obtained from several sources: from the milk fat, from the mobilization of triglycerides from the fat tissue, or through the synthesis itself, called de novo synthesis. The de novo synthesis is responsible for the production of short $\left(\mathrm{C}_{4-10}\right)$ and medium-chain fatty acids (DEMEYER; DOREAU, 1999). In the case of medium-chain fatty acids, only about $50 \%$ are synthesized by the mammary gland. The longchain fatty acids and the remaining 50\% mediumchain fatty acids reach the mammary gland through the blood circulation. It is thus clear that the profile of fatty acids present in the diet can affect the milk fatty acid profile (LEITE; LANA, 2009).

According to Leite and Lana (2009), the milk fatty acid profile varies according to the relative production of each one of the sources of fatty acids of the mammary glands and the absorption of fatty acids from the diet. The lipids ingested by ruminants undergo important transformations in the rumen, called biohydrogenation (BUCCIONI et al., 2012), a process that occurs from the action of a bacterial enzyme together with the endogenous synthesis that takes place at the very tissue of animals.

Of the unsaturated fatty acids, the conjugated linoleic acid (CLA) is noteworthy for its proven anticarcinogenic effect that prevents the occurrence of cardiovascular diseases (BAUMAN; GRIINARI, 2001). The term CLA refers to the mixture of positional and geometric isomers of linoleic acid (LA) (ANDRADE et al., 2012). Of the isomers, cis9, trans-11, known as rumenic acid, predominates 
in milk and derivatives, constituting over $90 \%$ of the CLA content in the milk fat (STANTON et al., 2014) and, together with the isomer trans-10 cis-12, they are the most widely studied ones (NUNES; TORRES, 2010).

Because of the many oil-extraction methods, the chemical composition of palm kernel cake, a by-product from oil extraction, has ether extract contents that can range from $0.5 \%$ to $12.23 \%$ (BRASIL, 2005). Recent studies seek to qualify such feedstuffs and determine their optimal levels of inclusion in ruminant diets that can enable animal productivity and preferably that can provide quality to their products (meat and milk), allow a reduction of costs with feeding, and increase profitability of production systems (OLIVEIRA et al., 2012). Thus, the aim of the present study was to evaluate the effect of inclusion of palm kernel cake in diets for confined cows on the fatty acid profile of their milk.

\section{Material and Methods}

The experiment was conducted on Paulistinha farm, in the city of Macarani, BA, Brazil, complying with the ethical principles approved by the Committee of Ethics of Southwest Bahia State University, and following the technical norms of biosafety and ethics. The experiment included 12 Holstein $\times$ Zebu crossbred cows (blood ranging from $1 / 2$ to $3 / 4$ Holstein) at the third or fourth lactation, with previous milk yield between 2,500 and 3,500 $\mathrm{kg}$, adjusted for 300 days, and at $64 \pm 13.32$ days in milk on average at the beginning of the experimental period. The 12 cows were distributed in a triple $4 \times 4$ Latin square with four 19-day experimental periods, of which the first 14 were used for adaptation. The following treatments were tested: 1) control (no inclusion of palm kernel cake); 2) inclusion of $50 \mathrm{~g}$ $\mathrm{PKC} / \mathrm{kg}$ in the total dry matter (TDM); 3) inclusion of $100 \mathrm{~g} \mathrm{PKC} / \mathrm{kg}$ in the TDM; and 4) inclusion of $150 \mathrm{~g} \mathrm{PKC} / \mathrm{kg}$ in the TDM. The roughage utilized was sugarcane (Saccharum officinarum) variety
RB 72454 , treated with $1 \%$ of a mixture of urea and ammonium sulfate $(9: 1)$ in the experimental phase. Following the recommendations of Santos et al. (2011), for a period of seven days before the onset of the experiment, cows received the roughage containing only $0.5 \%$ of the mixture of urea aiming to acclimate to this ingredient added to the roughage. The concentrate supplementation level was defined by the isoproteic and isoenergetic balance of the diets according to NRC (2001) to meet the requirements for maintenance, a body weight gain of $0.15 \mathrm{~kg} /$ day, and production of $15 \mathrm{~kg}$ milk/day (Table 1).

Table 1. Proportion of ingredients, on a dry matter basis.

\begin{tabular}{lcccc}
\hline \multirow{2}{*}{ Feedstuff (\%) } & \multicolumn{4}{c}{ Palm kernel cake level $(\mathbf{g} / \mathbf{k g})$} \\
\cline { 2 - 5 } & $\mathbf{0}$ & $\mathbf{5 0}$ & $\mathbf{1 0 0}$ & $\mathbf{1 5 0}$ \\
\hline Sugarcane & 68.40 & 64.92 & 61.01 & 57.50 \\
Cornmeal & 22.74 & 22.16 & 21.94 & 21.33 \\
Soybean meal & 7.08 & 6.59 & 6.20 & 5.69 \\
Palm kernel cake & 0.00 & 4.30 & 9.16 & 13.85 \\
Mineral salt $^{1}$ & 1.01 & 1.02 & 1.01 & 1.02 \\
Dicalcium & 0.50 & 0.42 & 0.31 & 0.21 \\
phosphate & & 0.32 & 0.35 & 0.38 \\
Limestone & 0.25 & 0.35 \\
\hline
\end{tabular}

${ }^{1}$ Composition: calcium - $200 \mathrm{~g}$; cobalt - $200 \mathrm{mg}$; copper - 1,650 mg; sulfur - $12 \mathrm{~g}$; iron - $560 \mathrm{mg}$; fluorine - (max) $1,000 \mathrm{~g}$; phosphorus $100 \mathrm{~g}$; iodine $195 \mathrm{mg}$; magnesium - 15 $\mathrm{g}$; manganese - 1,960 mg; nickel - $40 \mathrm{mg}$; selenium - $32 \mathrm{mg}$; sodium - $68 \mathrm{~g}$; Zinc - 6,285 mg.

The animals were housed in $16-\mathrm{m}^{2}$ individual covered stalls equipped with trough and drinker. The feed was supplied as a complete ration, twice daily, at $07 \mathrm{~h} 00$ and 15h00, after milking, ad libitum, so as to allow $10 \%$ as refusals. In each experimental period, roughage and supplement were collected to evaluate the chemical composition of the diets (Table 2). Chemical analyses of the palm kernel cake (Table 3) acquired from the Óleos de Palma SA AGRO INDUSTRIAL company, located in Taperoá, BA, Brazil, were performed. 
Table 2. Chemical composition of sugarcane and diets.

\begin{tabular}{|c|c|c|c|c|c|}
\hline \multirow{2}{*}{ Component } & \multirow{2}{*}{$\begin{array}{l}\text { Sugarcane } \\
\text { + urea }\end{array}$} & \multicolumn{4}{|c|}{ Palm kernel cake level (g/kg) } \\
\hline & & $\mathbf{0}$ & 50 & 100 & 150 \\
\hline Brix $^{1}$ & 18.51 & - & - & - & - \\
\hline Dry matter (g DM/kg) & 297.1 & 377.2 & 388.6 & 402.9 & 417.4 \\
\hline Crude protein (g/kg DM) & 107.1 & 123.1 & 123.5 & 123.6 & 127.1 \\
\hline Ether extract (g/kg DM) & 13.8 & 16.2 & 17.9 & 20.0 & 22.5 \\
\hline $\mathrm{NDFap}^{2}(\mathrm{~g} / \mathrm{kg} \mathrm{DM})$ & 585.4 & 446.5 & 432.7 & 438.8 & 447.9 \\
\hline Acid detergent fiber (g/kg DM) & 485.8 & 382.9 & 384.6 & 394.2 & 377.0 \\
\hline Non-fibrous carbohydrates (g/kg DM) & 343.7 & 445.9 & 455.1 & 444.5 & 426.5 \\
\hline Total carbohydrates (g/kg DM) & 867.5 & 851.2 & 848.9 & 847.0 & 840.5 \\
\hline $\operatorname{Lignin}(\mathrm{g} / \mathrm{kg} \mathrm{DM})$ & 98.5 & 49.2 & 70.0 & 82.9 & 99.9 \\
\hline
\end{tabular}

${ }^{1}$ Concentration of soluble sugars in sugarcane. ${ }^{2}$ Neutral detergent fiber corrected for ash and protein.

Table 3. Chemical composition of palm kernel cake.

\begin{tabular}{lc}
\hline Component & $\begin{array}{c}\text { Palm kernel } \\
\text { cake }\end{array}$ \\
\hline Dry matter (g DM/kg) & 922.5 \\
Crude protein $(\mathrm{g} / \mathrm{kg} \mathrm{DM})$ & 143.4 \\
Ether extract $(\mathrm{g} / \mathrm{kg} \mathrm{DM})$ & 105.6 \\
NDFap $^{1}(\mathrm{~g} / \mathrm{kg} \mathrm{DM})$ & 656.3 \\
Acid detergent fiber $(\mathrm{g} / \mathrm{kg} \mathrm{DM})_{\text {Lignin }(\mathrm{g} / \mathrm{kg} \mathrm{DM})}$ & 464.2 \\
Mineral matter $(\mathrm{g} / \mathrm{kg} \mathrm{DM})$ & 183.1 \\
\hline
\end{tabular}

${ }^{1}$ Neutral detergent fiber corrected for ash and protein.

Milk yield was assessed form the 15th to the 19th days of each experimental period, in two daily weighings. Milk samples from the 1 st and 2nd milkings (with calf at foot) of the 16th day were collected in the amount of $1 \%$ of the daily production of each animal, for determination of protein, as described by Silva and Queiroz (2002); and fat, lactose, solids nonfat, and total solids as described by Pregnolato and Pregnolato (1985) (Table 4). One hundred milliliters of milk from these samples were collected from daily production and frozen for subsequent analysis of the milk fatty acid profile.
Table 4. Composition of milk from lactating cows fed diets with levels of palm kernel cake.

\begin{tabular}{lcccc}
\hline \multirow{2}{*}{ Composition (\%) } & \multicolumn{4}{c}{ Palm kernel cake level (g/kg) } \\
\cline { 2 - 5 } & $\mathbf{0}$ & $\mathbf{5 0}$ & $\mathbf{1 0 0}$ & $\mathbf{1 5 0}$ \\
\hline Protein & 3.1 & 3.0 & 3.1 & 3.0 \\
Fat & 4.0 & 4.2 & 4.2 & 4.3 \\
Lactose & 4.6 & 4.6 & 4.6 & 4.6 \\
Solids nonfat & 8.4 & 8.3 & 8.4 & 8.3 \\
Total solids & 12.3 & 12.5 & 12.6 & 12.6 \\
\hline
\end{tabular}

For the extraction of total lipids from the fresh milk, $50 \mathrm{~mL}$ of each thawed sample were centrifuged at $12,000 \mathrm{rpm}$ for $30 \mathrm{~min}$ at $4{ }^{\circ} \mathrm{C}$, in a microcentrifuge (Himac CF-16RX II) and the fat was collected and stored in Eppendorf tubes for later analysis (REVENEAU, 2008). The fatty acid methyl esters were obtained by the procedure described by Bannon et al. (1982), with modifications described by Simionato et al. (2010). Fatty acid methyl esters were analyzed by gas chromatography in a Thermo Finnigan chromatograph (model Trace-GC-Ultra) equipped with a flame ionization detector (FID) and fused silica capillary column (BPX-70; $120 \mathrm{~m}, 0.25$ $\mathrm{mm}$ ID). Gas flow rates were $6.5 \mathrm{~mL} \cdot \mathrm{min}^{-1}$ for 
the carrier gas $\left(\mathrm{H}_{2}\right) ; 30 \mathrm{~mL} \cdot \mathrm{min}^{-1}$ for the auxiliary gas $\left(\mathrm{N}_{2}\right) ; 30 \mathrm{~mL} \cdot \mathrm{min}^{-1}$ for $\mathrm{H}_{2}$; and $250 \mathrm{~mL} \cdot \mathrm{min}^{-1}$ for the synthetic air. The sample split ratio was 90:10. Injection volumes were $1.2 \mu \mathrm{L}$. The peak areas of fatty acid methyl esters were determined using Chrom Quest 4.1 software. The fatty acids were identified by checking the equivalent chain length (ECL) of the peaks and comparing the retention times of the fatty acid methyl ester standards containing the linoleic acid isomers c9t11 and t10c12 (189-19, O-5632 and O-5626, Sigma, USA). The ECL values were determined as proposed by Visentainer and Franco (2006).
The data were evaluated by analyses of variance and regression, using the System for Statistical and Genetic Analyses - SAEG (2007). Statistical models were chosen according to the significance of the regression coefficients, using the " $F$ " test at 5\% probability level and the coefficient of determination $\left(\mathrm{R}^{2}\right)$.

\section{Results and Discussion}

Inclusion of palm kernel cake did not change the concentrations of the caproic $\left(\mathrm{C}_{6: 0}\right)$, caprylic $\left(\mathrm{C}_{8: 0}\right)$, and capric $\left(\mathrm{C}_{10: 0}\right)$ short-chain fatty acids (SCFA) (Table 5).

Table 5. Short-chain fatty acid composition of milk from cows fed diets with levels of palm kernel cake.

\begin{tabular}{lcccccccc}
\hline & $\begin{array}{c}\text { Fatty acid } \\
\text { (mg/g) }\end{array}$ & $\mathbf{0}$ & $\mathbf{5 0}$ & $\mathbf{1 0 0}$ & $\mathbf{1 5 0}$ & \multirow{2}{*}{ Eq. ${ }^{\mathbf{1}}$} & \multirow{2}{*}{$\mathbf{C V}(\mathbf{\%})^{\mathbf{2}}$} & \multirow{2}{*}{$\mathbf{P}^{\mathbf{3}}$} \\
\cline { 2 - 5 } & 2.04 & 2.42 & 2.34 & 2.45 & 2.31 & 46.24 & 0.320 \\
$\mathrm{C}_{6: 0}$ & 2.13 & 1.72 & 1.66 & 2.02 & 1.88 & 29.35 & 1.880 \\
$\mathrm{C}_{8: 0}$ & 5.04 & 4.40 & 4.08 & 4.90 & 4.60 & 23.53 & 1.862 \\
$\mathrm{C}_{10: 0}$ & & & &
\end{tabular}

${ }^{1}$ Regression equation; ${ }^{2}$ Coefficient of variation; ${ }^{3}$ Probability of error.

The short-chain fatty acids originate in the de novo synthesis, in which an intense lipogenic activity occurs from acetate and $\beta$-hydroxybutyrate, which are formed in the rumen (DAVIS; COLLIER, 1985). The main metabolic pathway of the de novo synthesis involves two lipogenic enzymes: acetyl-CoA carboxylase and fatty acid synthetase. The former is responsible for the formation of malonyl-CoA from acetate, and the latter catalyzes the condensation of malonyl-CoA to acetyl-CoA and butyryl-CoA, produced from the metabolism of acetate and $\beta$-hydroxybutyrate, respectively (CHILLIARD et al., 2000). The concentrations of caproic $\left(\mathrm{C}_{6: 0}\right)$ and caprylic $\left(\mathrm{C}_{8: 0}\right)$ fatty acids were not changed, probably because they are synthesized from $\beta$-hydroxybutyrate and acetate, mainly through two other pathways that do not involve malonylCoA (FOX et al., 2015).
Concentrations of lauric $\left(\mathrm{C}_{12: 0}\right)$ and myristic $\left(\mathrm{C}_{14: 0}\right)$ medium-chain fatty acids (MCFA) increased by 0.835 and $0.668 \mathrm{mg} / \mathrm{g}$, respectively, with every unit of palm kernel cake added (Table 6).

The alteration in the composition of short- and medium-chain fatty acids is associated with a reduction in milk fat content (AVILA et al., 2000).

Farias (2012) evaluated the centesimal composition of the fatty acids present in palm kernel cake and observed that those at highest percentages were: lauric $\left(\mathrm{C}_{12: 0}\right)(47.40 \%)$, myristic $\left(\mathrm{C}_{14: 0}\right)(16.66 \%)$, palmitic $\left(\mathrm{C}_{16: 0}\right)(7.99 \%)$, and oleic $\left(C_{18: \ln -9 c}\right)(13.84 \%)$. According to Farias (2012), the increased concentration of lauric $\left(\mathrm{C}_{12: 0}\right)$ and myristic $\left(\mathrm{C}_{14: 0}\right)$ medium-chain fatty acids in the milk might have been influenced by the higher percentages of these fatty acids in the palm kernel cake. In the 
present study, the results were similar, probably with fatty acid composition from palm kernel cake containing higher levels of lauric $\left(\mathrm{C}_{12: 0}\right)$ and myristic $\left(\mathrm{C}_{14: 0}\right)$ fatty acids.

Table 6. Medium-chain fatty acid composition of milk from cows fed diets with levels of palm kernel cake.

\begin{tabular}{|c|c|c|c|c|c|c|c|}
\hline \multirow{2}{*}{$\begin{array}{c}\text { Fatty acid } \\
(\mathrm{mg} / \mathrm{g})\end{array}$} & \multicolumn{4}{|c|}{ Palm kernel cake level (g/kg) } & \multirow{2}{*}{ Eq. ${ }^{1}$} & \multirow{2}{*}{$\mathrm{CV}(\%)^{2}$} & \multirow{2}{*}{$\mathbf{P}^{3}$} \\
\hline & $\mathbf{0}$ & 50 & 100 & 150 & & & \\
\hline $\mathrm{C}_{12 ; 0}$ & 6.12 & 5.93 & 6.84 & 8.46 & 4 & 22.52 & 0.003 \\
\hline $\mathrm{C}_{14: 0}$ & 14.56 & 14.55 & 13.35 & 17.17 & 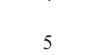 & 16.9 & 0.010 \\
\hline $\mathrm{C}_{14: 1}$ & 1.27 & 0.87 & 1.39 & 1.38 & 1.23 & 42.27 & 0.094 \\
\hline $\mathrm{C}_{15: 0}$ & 1.44 & 0.98 & 1.06 & 0.98 & 6 & 25.77 & 0.002 \\
\hline $\mathrm{C}_{15: 1}$ & 0.19 & 0.25 & 0.33 & 0.21 & 0.25 & 70.45 & 0.249 \\
\hline $\mathrm{C}_{16: 0}$ & 37.77 & 36.3 & 35.35 & 32.72 & 35.53 & 12.57 & 0.095 \\
\hline $\mathrm{C}_{16: 1}$ & 1.85 & 1.61 & 1.61 & 1.70 & 1.69 & 26.70 & 0.594 \\
\hline
\end{tabular}

${ }^{1}$ Regression equation; ${ }^{2}$ Coefficient of variation; ${ }^{3}$ Probability of error. ${ }^{4} \hat{Y}=4.743+0.835 \mathrm{x}, \mathrm{R}^{2}=0.21 ;{ }^{5} \hat{\mathrm{Y}}=13.147+0.668 \mathrm{x}, \mathrm{R}^{2}=$ $0.06 ;{ }^{6} \hat{Y}=1.472-0.133 x, R^{2}=0.16$.

The concentration of pentadecanoic $\left(\mathrm{C}_{15: 0}\right)$ fatty acid (Table 6) decreased linearly $(\mathrm{P}=0.002)$ by 1.33 with every unit of palm kernel cake added.

The pentadecanoic $\left(\mathrm{C}_{15: 0}\right)$ saturated fatty acid present in milk is synthesized in the rumen and reaches the mammary gland through the blood, originating from the bacterial synthesis in the rumen (MASSART-LËEN et al., 1983). The importance of the nutrient-capture capacity of the bloodstream to the synthesis of milk components, according to Madsen et al. (2004), is positively correlated with the extraction of triglycerides by the mammary gland, and limited extraction results from a reduced synthesizing ability of this gland.

The myristoleic $\left(\mathrm{C}_{14: 1}\right)$, pentadecenoic $\left(\mathrm{C}_{15: 1}\right)$, palmitic $\left(\mathrm{C}_{16: 0}\right)$, and palmitoleic $\left(\mathrm{C}_{16: 1}\right)$ mediumchain fatty acids were not influenced by inclusion of palm kernel cake in the diet. It is important to evaluate the milk from the nutraceutical food perspective, and among the estimated medium-chain fatty acid contents, special attention should be given to the $\mathrm{C}_{16: 0}$ (palmitic) and $\mathrm{C}_{14: 0}$ (myristic) saturated fatty acids. It should be stressed that myristic acid is the most hypercholesterolemic and has a four-time greater potential to elevate the plasma cholesterol concentration than palmitic acid (ROSSATO et al., 2009). Nevertheless, Chowdhury et al. (2014) gathered evidence on the association between fatty acids and coronary disease and asserted that the current evidence does not support the hypothesis that elevated consumption of polyunsaturated fatty acids and low consumption of total saturated fatty acids affect the occurrence of cardiovascular diseases.

The decreased proportion of short- and medium-chain fatty acids may be due to the reduced number of de novo synthesis precursors acetate and $\beta$-hydroxybutyrate, resulting from rumen fermentation, or to the direct inhibition of the enzymatic complex, involved in the de novo synthesis by the action of the long-chain fatty acids of vegetable oils (PALMQUIST et al., 1993). In the present study, there might have been inhibition of the enzymatic complex involved in the de novo synthesis and reduction of acetate production in the rumen, because when the microorganisms' ability to saturate fatty acids is exceeded, unsaturated fatty acids accumulate and interfere with the rumen fermentation (NRC, 2001). 
No effects were observed $(\mathrm{P}>0.05)$ on the with inclusion of palm kernel cake in the diet concentrations of long-chain fatty acids (LCFA) (Table 7).

Table 7. Long-chain fatty acid composition of milk from cows fed diets with levels of palm kernel cake.

\begin{tabular}{|c|c|c|c|c|c|c|c|}
\hline \multirow{2}{*}{$\begin{array}{c}\text { Fatty acid } \\
(\mathrm{mg} / \mathrm{g})\end{array}$} & \multicolumn{4}{|c|}{ Palm kernel cake level (g/kg) } & \multirow{2}{*}{ Eq. ${ }^{1}$} & \multirow{2}{*}{$\mathrm{CV}(\%)^{2}$} & \multirow{2}{*}{$\mathbf{P}^{3}$} \\
\hline & $\mathbf{0}$ & 50 & 100 & 150 & & & \\
\hline $\mathrm{C}_{17: 0}$ & 0.64 & 0.42 & 0.50 & 0.49 & 0.51 & 50.24 & 0.234 \\
\hline $\mathrm{C}_{17: 1}$ & 0.46 & 0.62 & 0.35 & 0.26 & 0.42 & 119.10 & 0.336 \\
\hline $\mathrm{C}_{18: 0}$ & 6.91 & 6.37 & 7.45 & 6.86 & 6.90 & 28.52 & 0.618 \\
\hline $\mathrm{C}_{18: \ln -9 \text { trans }}$ & 0.94 & 0.90 & 1.06 & 0.88 & 0.94 & 25.26 & 0.228 \\
\hline $\mathrm{C}_{18: \ln -9 \text { cis }}$ & 15.72 & 13.59 & 15.17 & 14.83 & 14.83 & 15.29 & 0.150 \\
\hline $\mathrm{C}_{18: 2 \mathrm{n}-6 \text { tras }}$ & 0.47 & 0.46 & 0.47 & 0.48 & 0.47 & 48.83 & 0.520 \\
\hline $\mathrm{C}_{18: 2 \mathrm{n}-6 \text { cis }}$ & 1.04 & 1.13 & 1.11 & 1.12 & 1.10 & 29.13 & 0.223 \\
\hline $\mathrm{C}_{18: 3 \mathrm{n}-6}$ & 0.24 & 0.19 & 0.20 & 0.21 & 0.21 & 70.19 & 0.817 \\
\hline $\mathrm{C}_{18: 3 \mathrm{n}-3}$ & 0.10 & 0.11 & 0.13 & 0.11 & 0.11 & 47.92 & 0.521 \\
\hline $\mathrm{C}_{18: 2 \text { cis-9 } 9 \text { trans-11 }}$ & 0.18 & 0.17 & 0.23 & 0.19 & 0.19 & 52.87 & 0.501 \\
\hline $\mathrm{C}_{20: 0}$ & 0.25 & 0.28 & 0.24 & 0.24 & 0.25 & 67.48 & 0.948 \\
\hline $\mathrm{C}_{22 \cdot 0}$ & 0.51 & 0.38 & 0.84 & 0.54 & 0.57 & 75.62 & 0.083 \\
\hline
\end{tabular}

${ }^{1}$ Regression equation; ${ }^{2}$ Coefficient of variation; ${ }^{3}$ Probability of error.

During the fermentation process, lipolytic bacteria transform the unsaturated fatty acids, mainly the long-chain fatty acids (LCFA), into saturated $\mathrm{C}_{18: 0}$ (stearic), through the biohydrogenation process. Stearic acid is neither related to a serum cholesterol increase nor associated with the origin of cardiovascular problems, because once in the body, it undergoes modifications and becomes $\mathrm{C}_{18: \mathrm{ln} \text { - }}$ 9cis (oleic), considered a neutral fatty acid (MOTTA, 2005). Although stearic acid is the main product of rumen biohydrogenation of unsaturated fatty acids, some conditions affect biohydrogenation, e.g. the lipid content of the diet and the rumen $\mathrm{pH}$ (OLIVEIRA et al., 2007).

Farias (2012) observed that inclusion of palm kernel cake in diets for dairy cows on pasture changed the levels of LCFA, $\mathrm{C}_{18: 2 \mathrm{n}-6}$ (linoleic), $\mathrm{C}_{18: 2 t 10 \mathrm{c} 12}$ (CLA), and $\mathrm{C}_{20: 0}$ (arachidic). According to this author, the use of concentrate in the diet changes the milk fatty acid profile, due to the influence on the microbial fermentation factors, with alterations in the rumen fermentation pattern, and through species of rumen bacteria. In certain types of diets, the rumen environment is changed, and a part of biohydrogenation occurs in a way that CLA trans-10, cis-12 are produced. Bifidobacterium, Propionibacterium, Streptococus, and Lactobacillus have been pointed out as producers of CLA trans-10 cis-12. These bacteria are present in a larger number in the rumen in high-concentrate diets (JENKINS, 2008), making the greater production of this isomer in these types of diets consistent.

The LCFA can exert an influence on the other milk-incorporated components. According to Grummer (1991), the LCFA inhibit the incorporation of MCFA and SCFA in the milk fat, due to the action of the acetyl-CoA carboxylase enzyme. According to Palmquist et al. (1993), LCFA in the diet originating from body mobilization, resulting from a negative energy balance, inhibit the de novo synthesis in the mammary gland. 
The polyunsaturated, monounsaturated, and saturated fatty acids were not influenced $(\mathrm{P}>0.05)$ by the inclusion of palm kernel cake in the diet (Table 8).

Table 8. Fatty acid composition of milk from cows fed diets with levels of palm kernel cake.

\begin{tabular}{|c|c|c|c|c|c|c|c|}
\hline \multirow{2}{*}{$\begin{array}{c}\text { Fatty acid } \\
(\mathrm{mg} / \mathrm{g})\end{array}$} & \multicolumn{4}{|c|}{ Palm kernel cake level (g/kg) } & \multirow{2}{*}{ Eq. ${ }^{1}$} & \multirow{2}{*}{$\mathrm{CV} \%{ }^{2}$} & \multirow{2}{*}{$\mathbf{P}^{3}$} \\
\hline & $\mathbf{0}$ & 50 & 100 & 150 & & & \\
\hline PUFA $^{4}$ & 1.87 & 2.17 & 2.2 & 1.99 & 2.06 & 25.82 & 0.388 \\
\hline MUFA $^{5}$ & 20.4 & 18.71 & 19.85 & 19.34 & 19.58 & 15.06 & 0.547 \\
\hline $\mathrm{SFA}^{6}$ & 78.1 & 76.63 & 72.66 & 76.28 & 75.92 & 9.45 & 0.311 \\
\hline$n-6^{7}$ & 1.52 & 1.78 & 1.83 & 1.63 & 1.69 & 25.72 & 0.300 \\
\hline$n-3^{8}$ & 0.10 & 0.11 & 0.14 & 0.11 & 0.11 & 47.92 & 0.521 \\
\hline PUFA/SFA ${ }^{9}$ & 0.24 & 0.29 & 0.31 & 0.26 & 0.28 & 26.93 & 0.181 \\
\hline$n-6 / n-3^{10}$ & 18.82 & 28.06 & 15.83 & 18.05 & 20.06 & 118.91 & 0.615 \\
\hline CLA $^{11}$ & 0.25 & 0.28 & 0.24 & 0.24 & 0.25 & 67.48 & 0.948 \\
\hline
\end{tabular}

${ }^{1}$ Regression equation; ${ }^{2}$ Coefficient of variation; ${ }^{3}$ Probability of error. ${ }^{4} \mathrm{PUFA}$ - polyunsaturated fatty acids; ${ }^{5} \mathrm{MUFA}$ - monounsaturated fatty acids; ${ }^{6} \mathrm{SFA}$ - saturated fatty acids; ${ }^{7} \mathrm{n}-6$ - fatty acids of the omega 6 series; ${ }^{8} \mathrm{n}-3$ - fatty acids of the omega 3 series; ${ }^{9} \mathrm{PUFA} / \mathrm{SFA}$ ratio between polyunsaturated and saturated fatty acids; ${ }^{10} \mathrm{n}-6 / \mathrm{n}-3$ - ratio between omega 6 and omega 3 series fatty acids; ${ }^{11} \mathrm{CLA}$ conjugated linoleic acid.

No effects were observed with addition of palm kernel cake $(\mathrm{P}>0.05)$ on the fatty acids of the omega 6 and 3 series, or on the polyunsaturated/saturated or omega 6/omega 3 fatty acid ratios (Table 8).

According Simopoulos (2002), although the quantitative requirements for the omega 3 fatty acids have not been established yet, it is assumed that the ratio can range from $5: 1$ to $10: 1$. These values are different from that observed in this study, which was higher $20.06 \mathrm{mg} / \mathrm{g}$.

Despite the lack of differences for the omega 6/omega 3 ratio between the levels of inclusion of palm kernel cake, the mean values found here are much higher than the recommended values to decrease the risk of cancer and coronary problems, which should be below 4 (HAUG et al., 2007; MARTIN et al., 2006).

Conjugated linoleic acid (CLA) was not influenced $(\mathrm{P}>0.05)$ by inclusion of palm kernel cake in the diet, averaging $0.25 \mathrm{~g} / 100 \mathrm{~g}$ (Table 8 ), similarly to the $0.27 \mathrm{~g} / 100 \mathrm{~g}$ found by Farias (2012), who used this ingredient in diets for lactating cows and obtained a similar average value of $0.27 \mathrm{~g} / 100 \mathrm{~g}$.

Barbosa (2010) found that conjugated linoleic acid was approximately $44 \%$ higher in the treatment with palm kernel cake $(60 \%$ palm kernel cake from the roughage) as compared with control treatment. As stated by Leite and Lana (2009), the absorption of fatty acids from the diet is influenced by the biohydrogenation process, which is performed by the rumen microorganisms. The manipulation of this process through alterations in the diet can influence the synthesis of fatty acids beneficial to the human health, such as oleic acid and conjugated linoleic acid. Although the palm kernel cake has a high ether extract content $(10.56 \%)$, the increased EE content of the diets was not sufficient to change the concentration of CLA.

Inclusion of palm kernel cake in diets for lactating cows influences the medium-chain fatty acids, lauric $\left(\mathrm{C}_{12: 0}\right)$, myristic $\left(\mathrm{C}_{14: 0}\right)$, pentadecanoic $\left(\mathrm{C}_{15: 0}\right)$ and the $\mathrm{C}_{18: 2 \mathrm{n} \text {-6trans }}$ fatty acid contents in their milk. Up to the level of $15 \%$, it does not influence the concentrations of long-chain, polyunsaturated, 
monounsaturated, and saturated fatty acids, conjugated linoleic acid, or the omega 6 and omega 3 series fatty acids.

\section{Acknowledgments}

To Southwest Bahia State University and the National Council of Research and Scientific and Technological Development (CNPq) for the fellowship grant.

\section{References}

ANDRADE, J. C.; ASCENCA, K.; GULLAN, P.; HENRIQUES, M. S.; PINTO, J. M.; ROCHA-SANTOS, T. A. P.; FREITAS, A. F.; GOMEZ, A. M. Production of conjugated linoleic acid by food-grade bacteria: A review. International Journal of Dairy Technology, Amsterdam, v. 65, n. 4 , p. $467-481,2012$.

AVILA, C. D.; PETERS, E. J. de; PEREZ-MONTI, H. Influences of saturation ratio of supplemental dietary fat on digestion and milk yield in dairy cows. Journal of Dairy Science, Savoy, v. 80, n. 9, p. 2204-2212, 2000.

BANNON, C. D.; BREEN, G. J.; CRASKE, J. D.; HAI, N. T.; HARPER, N. L.; O'ROURKE, K. L. Analysis of fattu acid methyl esters with high accuracy and reliability. Journal of Chromatography, Balmain, v. 247, n. 1, p. 7189, 1982.

BARBOSA, N. G. S. Torta de amêndoa de dendê: consumo, digestibilidade, metabolismo ruminal e desempenho leiteiro em bubalinos. 2010. Tese (Doutorado em Zootecnia) - Universidade Federal de Minas Gerais, Escola de Veterinária, Belo Horizonte.

BAUMAN, D. E.; GRIINARI, J. M. Regulation and nutritional manipulation of milk fat: low-fat milk syndrome. Livestock Production Science, Amsterdam, v. 70, n. 1-2, p. 15-29, 2001.

BRASIL. Ministério da Agricultura e Abastecimento. Sindicato Nacional da Indústria de Alimentação Animal. Associação Nacional dos Fabricantes de Rações. Compêndio brasileiro de alimentação animal. São Paulo: ANFAR/CBNA/SDR, 2005. 2004 p.

BUCCIONI, A.; DECANDIA, M.; MINIERI, S.; MOLLE, G.; CABIDDU, A. Lipid metabolism in the rumen: New insights on lipolysis and biohydrogenation with an emphasis on the role of endogenous plant factors. Animal Feed Science and Technology, Amsterdam, v. 174, n. 1-2, p. 1-25, 2012.
CÂNDIDO, R. S. Avaliação da qualidade do biodiesel produzido por transesterificação e armazenamento em diferentes recipientes. In: CONGRESSO DA REDE BRASILEIRA DE TECNOLOGIA DO BIODIESEL, 3., 2009, Brasília. Anais... Brasília: [s.n], 2009. p. 45-46.

CHILLIARD, Y.; FERLAY, A.; MANSBRIDGE, R. M.; DOREAU, M. Ruminant milk fat plasticity: nutritional control of saturated, polyunsaturated, trans and conjugated fatty acids. Annales de Zootechnia, SaintGenès-Champanelle, v. 49, n. 3, p. 181-205, 2000.

CHOWDHURY, R.; WARNAKULA, S.; KUNUTSOR, S.; CROWE, F.; WARD, H. A.; JOHNSON, L.; FRANCO, O. H.; BUTTERWORTH, A. S.; FOROUHI, N. G.; THOMPSON, S. G.; KHAW, K.; MOZAFFARIAN, D.; DANESH, J.; ANGELANTONIO, E. D. Association of dietary, circulating, and supplement fatty acids with coronary risk. Annals of Internal Medicine, v. 160, n. 6 , p. 398-406, 2014.

COSTA, D. A.; LOURENÇO JÚNIOR, J. B.; FERREIRA, G. D. G.; SANTOS, N. F. A.; GARCIS, A. R.; MONTEIRO, E. M. M. Avaliação nutricional da torta de dendê para suplementação de ruminantes na amazônia oriental. Amazônia: Ciência \& Desenvolvimento, Belém, v. 4, n. 8, p. 83-101, 2009.

DAVIS, S. R.; COLLIER, R. J. Mammary blood flow and regulation of substrate supply for milk synthesis. Journal of Dairy Science, Savoy, v. 68, n. 4, p. 1041-1058, 1985.

DEMEYER, D.; DOREAU, M. Targets and procedures for altering ruminant meat and milk lipids. Proceeding sof the Nutrition Society, v. 58, n. 3, p. 593-607, 1999.

FARIAS, M. M. S. Torta de dendê oriunda da produção de biodiesel em suplementos para vacas lactantes a pasto: qualidade do leite e do queijo. 2012. Tese (Doutorado em Zootecnia) - Escola de Medicina Veterinária e Zootecnia. Universidade Federal da Bahia, Salvador.

FOX, P. F.; MCSWEENEY, P. L. H.; UNIACKE, T.; O'MAHONY, J. A. Dairy chemistry and biochemistry. $2^{\text {th }}$ ed. New York: Springer, 2015. 584 p.

GRUMMER, R. R. Effect of feed on the composition of milk fat. Journal of Dairy Science, Savoy, v. 74, n. 9, p. 3244-3257, 1991.

HAUG, A.; HøSTMARK, A. T.; HARSTAD, O. M. Bovine milk in human nutrition - a review. Lipids in Health and Disease, London, v. 6, n. 25, p. 25-40, 2007.

JENKINS, T. C. Board-invited review: recent advances in biohidrogenation of unsaturated fatty acids within the rumen microbial ecosystem. Journal of Animal Science, Champaign, v. 86, n. 2, p. 397- 412, 2008. 
KENNELLY, J. J. The fatty acid composition of milk fat as influenced by feeding oilseeds. Animal Feed Science and Technology, Amsterdam, v. 60, n. 3-4, p. 137-152, 1996.

LEITE, L. C.; LANNA, D. P. D. Avanços no estudo do metabolismo de lipídios: perfil da gordura depositada na carne ou secretada no leite de ruminantes. In: SIMPÓSIO INTERNACIONAL AVANÇOS EM TÉCNICAS DE PESQUISA EM NUTRIÇÃO DE RUMINANTES, 2., 2009, Pirassununga. Anais... Pirassununga: Editora 5D, 2009. p. 147-164.

MA, F.; HANNA, M. A. Biodiesel production: a review. Bioresource Technology, Miramar, v. 10, n. 1, p. 1-15, 1999.

MADSEN, T. G.; NIELSEN, L.; NIELSEN, M. O. Mammary nutrient uptake in response to dietary supplementation of rumen protected lysine and methionine in late and early lactating dairy goats. Small Ruminant Research, Amsterdam, v. 56, n. 1-3, p. 151164, 2004.

MARTIN, C. A.; ALMEIDA, V. V.; RUIZ, M. R.; VISENTAINER, J. E. L.; MATSHUSHITA, M.; SOUZA, N. E.; VISENTAINER, J. V. Ácidos graxos poliinsaturados ômega-3 e ômega-6: importância e ocorrência em alimentos. Revista Nutrição, Campinas, v. 19, n. 6, p. 761-770, 2006.

MASSART-LËEN, A. M.; ROETS, E.; PEETERS, G.; VERBEKE, R. Propionate for fatty acid synthesis by mammary gland of the lactanting goat. Journal of Dairy Science, Savoy, v. 66, n. 7, p. 1445-1454, 1983.

MOTTA, V. T. Bioquímica. Caxias do Sul: Educs, 2005. $332 \mathrm{p}$.

NATIONAL RESEARCH COUNCIL - NRC. Nutrient requirements of dairy cattle. $7^{\text {th }}$ ed. Whashington: National Academy Press, 2001. 242 p.

NUNES, J. C.; TORRES, A. G. Fatty acid and CLA composition of Brazilian dairy products, and contribution to daily intake of CLA. Journal of Food Composition and Analysis, v. 23, n. 8, p. 782-789, 2010.

OLIVEIRA, M. A.; REIS, R. B.; LADEIRA, M. M.; PEREIRA, I. G.; FRANCO, G. L.; SATURNINO, H. M.; COELHO, S. G.; ARTUNDUAGA, M. A. T.; FARIA, B. N.; SOUZA JÚNIOR J. A. Produção e composição do leite de vacas alimentadas com dietas com diferentes proporções de forragem e teores de lipídeos. Arquivo Brasileiro de Medicina Veterinária e Zootecnia, Belo Horizonte, v. 59, n. 3, p. 759-766, 2007.
OLIVEIRA, R. L.; CÂNDIDO, E. P.; LEÃO, A. G.; SILVA; T. M. A nutrição de ruminantes no Brasil. In: DEMINICIUS, B. B.; MARTINS, C. B.; SIQUEIRA, J. B. Tópicos especiais em ciência animal I: coletânea da I Jornada Científica da Pós-Graduação em Ciências Veterinárias da Universidade Federal do Espírito Santo. ALEGRE: CAUFES. p. 11-22, cap. 2, 2012.

PALMQUIST, D. L.; BEAULIEU, A. D.; BARBANO, D. M. Feed and animal factors influencing milk fat composition. Journal of Dairy Science, Madison, v. 76, n. 6, p. 1753-771, 1993.

PREGNOLATO, W.; PREGNOLATO, N. P. Métodos químicos e físicos para análise de alimentos. In: PREGNOLATO. Normas analíticas do Instituto Adolfo Lutz. 3. ed. São Paulo: Instituto Adolfo Lutz, 1985. v. 1, $533 \mathrm{p}$.

REVENEAU, C. Dietary source and availibility of fatty acids to manipulate ruminal protozoa, metabolism of fat, and milk fatty acid profile in lactating dairy cows. 2008. Thesis (Doctor in Physiology) - Ohio State University, Columbus.

ROSSATO, L. V.; BRESSAN, M. C.; RODRIGUES, E. C.; CAROLINO, M. I. A. C. M.; BESSA, R. J. B.; ALVES, S. P. P. Composição lipídica de carne bovina de grupos genéticos taurinos e zebuínos terminados em confinamento. Revista Brasileira de Zootecnia, Viçosa, MG, v. 38, n. 9, p. 1841-1846, 2009.

SANTOS, J. F.; DIAS JÚNIOR, G. S.; BITENCOURT, L. L.; LOPES, N. M.; SIÉCOLA JÚNIOR, S.; SILVA, J. R. M.; PEREIRA, R. A. N.; PEREIRA, M. N. Resposta de vacas leiteiras à substituição parcial de farelo de soja por ureia encapsulada. Arquivo Brasileiro de Medicina Veterinária e Zootecnia, Belo Horizonte, v. 63, n. 2, p. 423-432, 2011.

SILVA, D. J.; QUEIROZ, A. C. Análise de alimentos: métodos químicos e biológicos. 3. ed. Viçosa, MG: Editora UFV, 2002. 235 p.

SIMIONATO, J. I.; GARCIA, J. C.; SANTOS, G. T.; OLIVEIRA, C. C.; VISENTAINER, J. V.; SOUZA, N. E. Validation of the determination of fatty acids in Milk by gas chromatography. Journal of the Brazilian Chemical Society, São Paulo, v. 21, n. 3, p. 520-524, 2010.

SIMOPOULOS, A. P. The importance of the ratio of omega-6/omega-3 essential fatty acids. Biomedicine \& Pharmacotherapy, Washington, v. 56, n. 8, p. 365-379, 2002.

SISTEMA PARA ANÁLISE ESTATÍSTICA - SAEG. Sistema para análises estatísticas, versão 9.1. Viçosa, MG: UFV, 2007. 
STANTON, C.; MURPHY, J.; MCGRATH, E.; DEVERY, R. Animal feeding strategies for conjugated linoleic acid enrichment. Revista do Instituto de Laticínios Cândido Tostes, Juiz de Fora, v. 69, n. 3, p. 199-211, 2014.
SUE, T. T. Quality and characteristics of Malaysian palm kernel cakes/expellers. Palm Oil Development, n. 34 , p. 1-3, 2001.

VISENTAINER, J. V.; FRANCO, M. R. B. Ácidos graxos em óleos e gorduras: identificação e quantificação. São Paulo: Varela, 2006. 120 p. 
